\title{
Studi Penerapan Nilai Kasih Storge Orangtua Terhadap Anak di GMIT Jemaat Syalom Oinlasi
}

\author{
Anika Tusi, ${ }^{1}$ Nelci Nafalia Ndolu, ${ }^{2}$ Catur Prio Purnomo ${ }^{3}$ \\ 1,2,3nstitut Agama Kristen Negeri Kupang \\ 1anikatusi@gmail.com \\ nelcinafaliandolu@gmail.com \\ 33caturpriopurnomo@gmail.com
}

\begin{abstract}
This article focuses on the application of the value of parental love for children in Christian families in the GMIT Congregation of Syalom Oinlasi. The purpose of writing this article is to determine the form of storge love that has been trained by parents to children in order to form character and soft skills to love oneself and others. The research was conducted using the interview method, the results of which were processed by means of reduction and verification. The results of the study show that parents at GMIT Syalom Oinlasi congregation apply the value of storge love to their children in the form of protecting them from fighting, promiscuity by advising them repeatedly. Ensure that her children receive food, formal education and spiritual education to be actively involved in Bible studies in the Church. Parents also try to be role models in respect and honesty with themselves and others.
\end{abstract}

Keywords: Value of Storge Love, Parents, Children,

Abstrak: Artikel ini fokus pada penerapan nilai kasih storge orang tua terhadap anak dalam keluarga Kristen di GMIT Jemaat Syalom Oinlasi. Tujuan dari penulisan artikel ini adalah untuk mengetahui bentuk kasih storge yang telah dilatih orangtua kepada anak-anak dalam rangka membentuk karakter dan softskill mengasihi diri dan sesama. Penelitian dilakukan dengan metode wawancara yang hasil penelitiannya diolah dengan cara reduksi, dan verifikasi. Hasil dari penelitian menunjukan bahwa orang tua di GMIT Jemaat Syalom Oinlasi menerapkan nilai kasih storge terhadap anak-anak mereka dalam bentuk mengayomi anak-anak dari tindakan perkelahian, pergaulan bebas dengan cara menasehati mereka secara berulang-ulang. Memastikan anak- anaknya mendapat makanan, pendidikan formal dan pendidikan rohani aktif terlibat dalam kegiatan PAR di Gereja. Orang tua pun berusaha menjadi teladan dalam sikap menghormati, dan jujur terhadap diri sendiri dan sesama.

Kata kunci: Nilai Kasih Storge, Orang tua, Anak

\begin{tabular}{llll}
\hline Article History : & Received: 17-10-2020 & Revised: 20-12-2020 & Accepted: 28-12-2020
\end{tabular}

\section{Pendahuluan}

Tulisan ini dibuat sebagai upaya untuk memberikan pemaparan tentang penerapan nilai kasih storge dalam keluarga Kristen. Penulis menyadari bahwa kasih sangat penting bagi keluarga Kristen. Kasih merupakan hukum Tuhan yang utama dalam ajaran Alkitab dan 
kasih juga merupakan pengikat dalam keluarga Kristen. Susetyo menjelaskan bahwa kasih adalah perasaan yang dimiliki oleh setiap manusia, perasaan ini akan timbul apabila manusia memiliki rasa saling menyayangi. ${ }^{1}$

Kasih storge adalah kasih dalam keluarga, kasih orang tua kepada anaknya, dan kasih anak kepada orang tuanya. ${ }^{2}$ Kasih storge bukan hanya kasih antara orang tua kepada kepada anak-anaknya, melainkan juga kepada cucu-cucunya. Jenis kasih seperti ini pun tersirat di dalam Alkitab (Efesus 6:4) orang tua harus mengasihi anaknya dan cucu-cucunya, baik seorang ayah maupun seorang ibu bertanggungjawab untuk mengasihi anak-anaknya. Kasih menunjukan hubungan kasih mesra yang ada dalam keluarga atau rumah tangga. ${ }^{3}$

Orang tua memiliki peran yang sangat penting untuk menerapkan kasih storge kepada anak-anak. Orang tua diharapkan terus melatih anak untuk menerapkan nilai dari kasih storge. Penerapan nilai kasih storge bagi keluarga dalam diri anak tentunya akan mempengaruhi karakter dan masa depan anak. Karakter yang diharapkan adalah anak-anak mampu mengasihi diri sendiri dan sesamanya. Orang tua dalam hal ini juga harus mengerti dan memahami karakter anak sehingga dapat memainkan perannya dengan tepat. Dalam penerapan kasih orang tua harus bijaksana dalam memberikan kasih kepada anak-anaknya. Kasih adalah baik, yang membuat kasih berdampak baik atau buruk ialah ketepatan dalam penerapannya. Orang tua patut mengajarkan hal kasih dalam keluarga seperti kasih Yesus, tidak memandang kepada siapa dan untuk siapa tetapi harus berlaku untuk sesama umat manusia.

Keluarga Kristen adalah keluarga yang dibentuk atas insiatif Allah sendiri, oleh karena itu keluarga Kristen sebagai tempat bernaung dan berlindung bagi seluruh anggota keluarga. Untuk itu keluarga Kristen harus membuat suasana keluarga yang menyenangkan. Keluarga Kristen harus hidup saling mengasihi satu sama lain, itu merupakan satu bentuk kasih yang nyata menurut ajaran Kristen. Dengan mengasihi, maka kesadaran tentang pentingnya kasih dan mengasihi semakin besar. Jika kasih tidak ada dalam rumah tangga, maka rumah tangga akan sepi, gersang dan rumah tangga tidak akan bertahan. Keluarga Kristen akan bahagia jika orang tua mampu menerapkan kasih storge dalam kehidupan sehari-hari. ${ }^{4}$

\footnotetext{
${ }^{1}$ Benny Susetiyo, Kasih Itu Pembebasan (Yogyakarta: Yayasan Pustaka Utama, 2003), 34.

2 Jhon Drescher, Melakukan Buah Roh (Jakarta: BPK Gunung Mulia, 2008), 18.

${ }^{3}$ Brownlee Malcom, Pengambilan Keputusan Etis dan Faktor-Faktor di Dalamnya (Jakarta: BPK Gunung Mulia, 2006), 26.

${ }^{4}$ A Munthe, Firman Hidup (Jakarta: BPK Gunung Mulia, 2015), 50.
} 
Dalam pengamatan penulis, permasalahan yang sering ditemui adalah adanya sebagian keluarga Kristen yang kurang melatih dan menerapkan kasih storge kepada anak-anak. Kenyataan yang seperti ini penulis temukan di Jemaat Syalom Oinlasi Barat. Masalah yang peneliti lihat adalah orang tua lebih banyak memberikan kasih melalui materi dari pada memberi kasih sayang yang nyata seperti memberikan perhatian, melindungi anak, mengajarkan nilai kasih yang berkaitan dengan ajaran Alkitab. Banyak keluarga Kristen yang kurang menerapkan ajaran kasih dalam Alkitab terlebih kasih storge, hal ini mengakibatkan anak kurang menerapkan dalam dirinya maupun dalam lingkungan masyarakat.

Dengan melihat permasalahan ini maka orang tua memiliki tanggungjawab yang lebih untuk melatih anak-anak untuk menerapkan kasih storge. Penerapan kasih storge dapat diwujudkan dalam beberapa bentuk seperti mengayomi anak, mengayomi adalah menjaga atau menyelamatkan anak supaya terhindar dari ancaman, gangguan dan marabahaya. Orang tua selalu berusaha membuat anaknya merasa aman dalam perlindungannya. Dalam hal ini setiap orang tua harus memberikan perlindungan kepada anak-anaknya, agar anak dapat merasakan kasih orang tua dengan baik dalam keluarga. ${ }^{5}$ Memperhatikan anak, Perhatian adalah memberikan waktu bersama, kesediaan mendampingi bersama anak-anak, dan membantu mereka jika diperlukan. Segala sesuatu yang berhubungan dengan anak diatur oleh orang tua dan memenuhi kebutuhan anak. Tapi tak cukup untuk itu, anak juga membutuhkan perhatian orang tua yang sederhana seperti meluangkan waktu untuk berkumpul bersama. ${ }^{6}$

Bentuk lain dari penerapan kasih storge adalah orang tua harus memberi teladan yang baik untuk anak-anaknya, orang tua harus menjadi contoh dan teladan bagi anakanaknya baik dari perkataan, sikap dan tingkah laku. Teladan yang baik dari orang tua kepada anak yaitu seperti menanamkan nilai-nilai kejujuran dalam keluarga. Keluarga adalah tempat yang penting di mana anak memperoleh dasar dalam membentuk orang yang berhasil di lingkungan masyarakat. Wujud penerapan dari bentuk kasih storge berikutnya adalah penerapan sikap disiplin, disiplin dan kasih merupakan kebutuhan dasar setiap anak dalam upaya pembentukan karakter yang sehat. Kedua hal ini tidak bisa dipisahkan demikian juga dalam penerapanya, kasih dan disiplin harus diterapkan secara seimbang. Kasih adalah alasan, motif dan tujuan adanya disiplin dan disiplin merupakan perwujudan kasih itu sendiri.

\footnotetext{
${ }^{5}$ Yusuf. Rahman Praditya, Pelindung Diri (Jakarta: YPK Utama, 2020), 81.

${ }^{6}$ D. Singgih Gunarsa,. Psikologi Praktis Anak, Remaja dan Keluarga (Jakarta: BPK Gunung Mulia, 2008), 283.
} 
Di dalam keluarga Kristen orang tua harus menerapkan nilai kasih storge kepada anak secara teratur dan baik sehingga dengan sendirinya anak akan memperoleh latihan-latihan dasar dalam mengembangkan sikap sosial yang baik sehinga kebiasaan berprilaku dalam keluarga sesuai dengan ajaran orang tua. Orang tua menjadi guru bagi keluarganya dalam hal kehidupan dan kesaksian iman kepada Allah. Lingkungan keluarga merupakan tempat berlangsungnya sosialisasi yang berfungsi dalam pembentukan kepribadian sebagai makhluk individu, sosial, dan keagamaan. Keluarga Kristen diharapkan hidup saling mengasihi satu sama lain itu merupakan satu bentuk kasih yang nyata menurut ajaran Kristen. Keluarga Kristen akan bahagia jika orang tua mampu menerapkan kasih storge dalam kehidupan sehari-hari.

Tujuan dari tulisan ini adalah mendorong orang tua Kristen untuk lebih maksimal dalam menerapkan nilai kasih storge. Orang tua harus melatih anak bagaimana bentuk dari kasih itu dapat diterapkan dalam kehidupan mereka. Sehinga dengan hal ini karakter mereka dapat terbentuk dan menjadi anak yang mampu mengasihi diri sendiri ataupun sesamanya.

\section{Metode Penelitian}

Metode yang digunakan dalam penelitian ini adalah metode kualitatif. ${ }^{7}$ Sumber data utama dalam penelitian kualitatif adalah kata-kata dan tindakan yang didapat dari informan melalui wawancara. Peneliti menggunakan cara ini untuk mendapatkan informasi langsung tentang penerapan nilai kasih dalam keluarga Kristen di jemaat sebanyak lima keluarga. Teknik analisis data yang digunakan adalah reduksi data, display data. ${ }^{8}$ Mereduksi data berarti merangkum, memilih hal-hal yang pokok, memfokuskan pada hal-hal yang penting. Setelah data direduksi, maka langkah selanjutnya adalah menyajikan data. Langkah ketiga dalam analisis data kualitatif adalah penarikan kesimpulan dan verifikasi.

\section{Hasil dan Pembahasan}

\section{Hasil Penelitian}

Berikut merupakan kutipan verbatim dari penelitian yang dilakukan di jemaat Syalom Oinlasi Barat.

\begin{tabular}{|c|c|}
\hline Indikator & Kutipan \\
\hline Mengayomi & Mengayomi atau melindungi dalam keluarga \\
\hline
\end{tabular}

\footnotetext{
${ }^{7}$ Sugiyono, Metode Penelitian Kuantitatif , Kualitatif dan R\&D (Bandung: Alfabeta, 2019), 32.

${ }^{8}$ Ibid.249-252
} 


\begin{tabular}{|c|c|}
\hline & $\begin{array}{l}\text { wajib dilakukan karena adalah bentuk } \\
\text { tanggung jawab orang tua kepada anak untuk } \\
\text { menjauh dari hal-hal negatif seperti pergaulan } \\
\text { bebas, kecelakaan fisik, dan menjaga hubungan } \\
\text { dalam keluarga agar tetap utuh dalam kasih. } \\
\text { (AT J8, PB J8, J0 J8, dan IT J8). Memberikan } \\
\text { rasa percaya diri kepada anak dalam keluarga } \\
\text { (AS J8). Karena sebagai orang tua jika kita } \\
\text { mampu melindungi anak- anak dari pergaulan } \\
\text { bebas maka, anak- anak merasa selalu di } \\
\text { lindungi. Narasumber memahami bahwa } \\
\text { bentuk perlindungan orang tua kepada } \\
\text { anggota keluarga yaitu dengan melindungi } \\
\text { anak dari kecelakaan fisik seperti jatuh, } \\
\text { perkelahian, pergaulan bebas dan menjaga } \\
\text { kesehatan anak (AT J9, PB J9, J0 J9, AS J9, IT } \\
\text { J9). }\end{array}$ \\
\hline Perhatian & $\begin{array}{l}\text { Narasumber memahami bahwa selalu } \\
\text { meluangkan waktu kepada keluarga untuk } \\
\text { berada di tengah keluarga mendampingi anak- } \\
\text { anak dalam mengerjakan tugas-tugas anak, } \\
\text { menjaga tumbuh kembang anak dan selalu } \\
\text { memberikan kasih sayang sehingga anak-anak } \\
\text { merasa nyaman dalam keluarga } \\
\text { (AT J13, PB J 13, AS J13, IT J13). } \\
\text { Narasumber memahami bahwa bentuk } \\
\text { perhatian kepada setiap anggota keluarga } \\
\text { yaitu dengan selalu memperhatikan kebutuhan } \\
\text { rohani seperti pergi ke gereja, perhatian } \\
\text { tentang makanan, minuman, pakaian yang } \\
\text { dibutuhkan oleh setiap keluarga (AT J14, PB } \\
\text { J14, J0 J14, AS J14, IT J14). }\end{array}$ \\
\hline Teladan & $\begin{array}{l}\text { Narasumber memahami bahwa orang tua } \\
\text { memiliki tanggung jawab untuk menjadi } \\
\text { contoh atau teladan yang baik bagi anak, } \\
\text { karena orang tua adalah cerminan bagi anak } \\
\text { seperti sikap, perbuatan dan tinggkah laku } \\
\text { yang baik (AT J18, PB J18, JO J18, AS J18, IT } \\
\text { J18). Teladan orang tua adalah contoh dan } \\
\text { cerminan bagi anak-anak, jadi apa yang dibuat } \\
\text { oleh orang tua akan dilakukan oleh anak-anak. } \\
\text { Narasumber memahami bahwa bentuk teladan }\end{array}$ \\
\hline
\end{tabular}




\begin{tabular}{|c|c|}
\hline & $\begin{array}{l}\text { dari orang tua yaitu mengajarkan setiap } \\
\text { anggota keluarga tentang hal kasih seperti } \\
\text { saling mengasihi, perbuatan yang baik seperti } \\
\text { jujur, jangan bertengkar (AT J19, PB J19, IT } \\
\text { J19). Narasumber memahami bahwa sebagai } \\
\text { orang tua wajib mengajarkan setiap anggota } \\
\text { keluarga untuk saling mengasihi sesama } \\
\text { anggota keluarga, sehingga di luar lingkungan } \\
\text { keluarga, anak dapat melakukan hal tersebut } \\
\text { kepada sesama (J0 J19, AS J19). }\end{array}$ \\
\hline Menghormati & $\begin{array}{l}\text { Narasumber memahami bahwa saling } \\
\text { menghormati di dalam setiap anggota keluarga } \\
\text { merupakan suatu hal yang wajib dilakukan } \\
\text { dalam keluarga, sehingga tercipta suasana } \\
\text { yang harmonis dan penuh kasih contoh dari } \\
\text { bentuk menghormati anggota keluarga adalah } \\
\text { saling menunjukan rasa hormat, mendengar } \\
\text { ketika anggota keluarga sedang berbicara (AT } \\
\text { J23, PB J23, JO J23, AS J23, IT J23). Dengan rasa } \\
\text { saling menghormati maka setiap anggota } \\
\text { keluarga mengetahui tugas dan perannya } \\
\text { masing- masing dalam rumah. } \\
\text { Narasumber memahami bahwa selalu } \\
\text { memberikan dukungan kepada setiap anggota } \\
\text { keluarga tentang hal-hal yang positif (AT J24). } \\
\text { Narasumber yang lain memahami bahwa } \\
\text { dalam setiap anggota keluarga tidak } \\
\text { membeda-bedakan dalam menghormati, } \\
\text { seperti anak-anak selalu memberikan salam } \\
\text { kepada orang tua (PB J24, JO J24, AS J24, IT } \\
\text { J24). }\end{array}$ \\
\hline Disiplin & $\begin{array}{l}\text { Narasumber memahami bahwa setiap anggota } \\
\text { keluarga harus taat dan disiplin dalam } \\
\text { menggunakan waktu dan melakukan setiap } \\
\text { tugas dan tanggung jawab yang telah dibagi. } \\
\text { Setiap anggota keluarga juga wajib mengikuti } \\
\text { semua peraturan yang ada di dalam rumah } \\
\text { sehingga seluruh anggota keluarga tetap hidup } \\
\text { dalam memakai waktu dan mengikuti aturan- } \\
\text { aturan yang ada (AT J33, PB J33, AS J33, IT } \\
\text { J33). Narasumber yang satu memiliki }\end{array}$ \\
\hline
\end{tabular}




\begin{tabular}{|l|l|}
\hline & pemahaman yang berbeda yaitu dalam hal \\
disiplin. Jadi disiplin yang dilakukan oleh \\
orang tua dalam keluarga bukan saja waktu \\
tetapi orang tua juga harus menjadi contoh \\
bukan saja dengan kata-kata tetapi juga \\
dengan perbuatan (JO J33). \\
Bentuk disiplin orang tua kepada anggota \\
keluarga yaitu disiplin dalam menghargai \\
waktu yang ada dan perilaku anak. \\
Narasumber memahami bahwa bentuk disiplin \\
yang harus dilakukan oleh setiap anggota \\
keluarga adalah menghargai waktu yang ada \\
sehingga dalam melakukan sesuatu sesuai \\
dengan apa yang ditentukan dan disiplin \\
tentang perilaku anak (AT J34, PB J34, JO J34, \\
AS J34, IT J34). Disiplin waktu yang diterapkan \\
oleh orang tua kepada setiap anggota keluarga \\
merupakan hal yang wajib dilaksanakan, \\
sehingga dalam keluarga selalu menghargai \\
waktu yang ada.
\end{tabular}

\section{Pembahasan}

\section{Mengayomi}

Orang tua selaku narasumber di Jemaat Syalom Oinlasi Barat memahami dengan baik tentang mengayomi atau melindungi anggota keluarga sebagai tanggungjawab orang tua untuk menjaga setiap anggota keluarga tetap utuh di dalam kasih. Bentuk mengayomi yang dilakukan oleh orang tua di Jemaat Syalom Oinlasi Barat adalah dengan memberikan nasehat kepada anak-anak mereka untuk menghindari hal-hal negatif yang bisa saja terjadi dalam kehidupan mereka misalnya salah dalam bergaul, mengalami kecelakan fisik karena kurang hati-hati dalam bertindak. Nasehat tersebut dilakukan oleh orang tua ketika melakukan peribadahan keluarga.

Orang tua di jemaat Oinlasi memiliki peran penting dalam melindungi anak dari pergaulan bebas (Merokok, mengkomsumsi alkohol, pornografi) selain memberikan nasehat dalam peribadahan orang tua diharapkan mengawasi anak dengan baik ketika mereka bergaul di luar lingkungan keluarga. Orang tua tidak boleh ragu untuk menegur dan memberikan nasehat ketika anak sudah melakukan tidakan yang salah dan merugikan.

Untuk menuju proses dewasa yang lebih baik dan bebas dari masalah kehadiran orang tua sangat dibutuhkan oleh anak-anak yang belum bisa memahami mana yang 
salah dan mana yang benar. ${ }^{9}$ Orang tua diharapkan mengawasi anak dengan baik sehingga pergaulan anak di luar lingkungan keluarga dapat diketahui dengan baik. Dalam hal ini orang tua harus mendidik anak untuk mengasah kemampuan yang tepat dalam membuat keputusan yang sangat penting untuk bertumbuh menjadi anak yang berkenan kepada Allah dan manusia.

Berdasarkan pemaparan maka dapat dipastikan bahwa pengayoman orang tua terhadap anak-anak dalam keluarga Kristen merupakan wujud nyata dari penerapan nilai kasih storge.

\section{Perhatian}

Orang tua menyadari perannya dalam lingkungan keluarga untuk meluangkan waktu bersama setiap anggota keluarga dengan memberikan perhatian dan kasih sayang yang tulus kepada keluarga. Orang tua memiliki kewajiban yang tidak dapat dihindari, yaitu memenuhi kebutuhan rohani dan jasmani sehingga anak tersebut tumbuh dengan normal, sehat dan cerdas. ${ }^{10}$ Dari hal ini maka bentuk-bentuk dari perhatian orang tua yaitu perhatian secara jasmani, seperti makanan, pendidikan dan rohani seperti pergi ke gereja, sekolah minggu. Segala sesuatu yang berhubungan dengan anak diatur oleh orang tua dalam memenuhi kebutuhan anak, tetapi anak juga membutuhkan perhatian orang tua yang sederhana seperti meluangkan waktu untuk berkumpul bersama. ${ }^{11}$ Ini berarti bahwa perhatian orang tua kepada anak perlu dilakukan kepada setiap anggota keluarga. Perhatian orang tua mengenai makanan yaitu orang tua berusaha memenuhi kebutuhan nutrisi anak. Orang tua harus membiasakan anak dengan pola makan yang baik sehingga anak dapat mengatur pola makannya sendiri. Perhatian orang tua mengenai pendidikan yaitu orang tua sebagai pendidik pertama dan utama. Karena orang tua yang memberikan pendikan kepada anak-anak. Kegagalan dan keberhasilan anak dalam pendidikan adalah tanggung jawab dan kewajiban dari orang tua. Menurut Setiawan peran orang tua sebagai guru pertama dan utama bagi anak perlu kesiapan batin, karena tanpa kesiapan batin akan tampak orang tua sering mengeluh atas anaknya. Untuk itu sebagai orang tua berperan penting dalam membimbing dan memberi contoh kepada anak dalam pendidikan. ${ }^{12}$

\footnotetext{
${ }^{9}$ Herry Prasetyo, Agar Anak Merasa di Cintai (Jakarta: Duta Press, 2019), 51.

10 Elisabeth, Pembelajaran Pendidikan Agama Kristen Pada Anak Usia Dini ((Bandung: Bina Media Informasi, 2009), 14.

11 Singgih Gunarsa, "Menanamkan Disiplin Pada Anak," dalam Psikologi Perkembangan Anak dan Remaja, ed. Singgih Gunarsa (Jakarta: BPK Gunung Mulia, 2008), 86-87.

${ }^{12}$ Bukik Settiawan, Anak Bukan Kertas Kosong (Jakarta: Panda Media, 2015), 2.
} 
Bentuk perhatian orang tua yang tidak kalah penting adalah mengajarkan anak untuk rajin pergi ke Gereja karena dengan pergi ke gereja iman anak-anak dibentuk dalam Yesus Kristus. Ini adalah cara yang efektif dalam mengasuh anak-anak dalam memberikan ketrampilan dan menanamkan nilai-nilai pertumbuhan iman di dalam Yesus Kristus. Pembinaan rohani di sini mencakup upaya membawa anak kepada Yesus Kristus agar percaya kepadaNya atau membimbing mereka lebih mengenal Allah, rajin berdoa, rajin beribadah, gemar membaca Alkitab dan memahaminya, berdisiplin, dan hidup tertib serta bertanggung jawab. Jika demikian pembinaan rohani menjadi dasar bagi pertumbuhan watak anak. Kebutuhan rohani yang terpenuhi menjadi landasan yang amat baik bagi pertumbuhan moral dan karakter anak. Berdasarkan pemaparan, dapat dipastikan bahwa bentuk perhatian dari orang tua kepada anak perlu dilakukan di dalam kehidupan keluarga sebagai bentuk tanggung jawab orang tua dalam menanamkan nilai kasih kepada anak.

\section{Teladan}

Orang tua memahami dengan baik tentang teladan bagi anak yaitu orang tua sebagai contoh atau cerminan yang baik kepada anak-anak. Di lingkungan keluarga anak-anak mengikuti teladan orang tua mereka sebagai contoh dalam pertumbuhan hidup mereka. Bentuk teladan yang terwujud adalah anak-anak adalah yang saling mengasihi sesama dan saling menghormati anggota keluarga, sesama baik di lingkungan gereja ataupun di masyarakat. Bentuk lain dari teladan dari orang tua adalah menanamkan nilai-nilai kejujuran dalam keluarga. Ketika orang tua menghendaki kejujuran pada anaknya sedangkan ia tidak melaksanakan kejujuran, maka anak akan mengalami konflik dalam dirinya dan akan mengunakan ketidak konsistenan orang tua sebagai alasan untuk tidak melakukan apa yang diinginkan orang tua. ${ }^{13}$ Berkaitan dengan hal ini maka orang tua harus menjadi teladan yang baik bagi anak-anak dengan bersikap konsisten.

Ketika orang tua hadir sebagai teladan dan anak-anak mengagumi mereka dan ingin menjadi seperti mereka, maka anak-anak akan menguji gaya hidup dan nilainilainya untuk kemudian menjadi contoh dalam kehidupan mereka. Ini berita baik bagi orang tua Kristen, keteladanan orang tua juga akan dipakai oleh Roh Kudus dalam upaya meneruskan kehidupan anak-anak. ${ }^{14}$ Sebelum orang tua mengajarkan anak-anak untuk saling menghormati dan mengasihi sesama mereka lebih dulu menjadi contoh teladan yang baik yaitu menghormati dan mengasihi anak-anak dalam keluarga. Dalam hal ini orang tua mencontohkan teladan Yesus bahwa selain menjadi sahabat yang baik, Yesus

${ }^{13}$ Yusuf S, Psikologi Perkembangan Anak dan Remaja (Bandung: Rosda, 2009),134.
${ }^{14}$ M John Drescher, Melakukan Buah Roh, (Jakarta: BPK Gunung Mulia, 2015), 46. 
juga memberi teladan bagi umat-Nya agar selalu memberi pertolongan kepada orang yang membutuhkan tanpa mempertimbangkan perbedaan suku, agama, status dan budaya. Ini berarti bahwa orang tua perlu melakukan bentuk-bentuk teladan yang baik bagi anak dengan mengajarkan kepada anak tentang perbuatan yang baik di dalam keluarga.

\section{Saling Menghormati}

Orang tua memahami dengan baik tentang sikap saling menghormati yaitu setiap anggota keluarga wajib saling menghormati sehingga tercipta suasana harmonis dan penuh kasih. Bentuk rasa saling menghormati adalah menunjukan rasa hormat. Dalam hal ini bukan hanya anak yang menghormati orang tua, orang tua juga perlu menghormati anak-anak. Untuk menunjukan rasa saling menghormati dalam keluarga, orang tua tentu menghormati hak anak dengan cara tidak memaksakan kehendak serta memberi dukungan selama hal itu positif. Untuk menunjukan rasa hormat terhadap anggota keluarga adalah saling memperhatikan dan mendengarkan. Menjadi pendengar yang baik ketika keluarga bercerita, berbagi dan berkeluh kesah. Berkaitan dengan hal ini hindari sikap acuh tak acuh saat salah satu anggota berbicara.

Menurut Wijanarko orang tua patut mengajarkan perilaku saling menghormati kepada setiap anggota keluarga. Kalau sikap dan perilaku saling menghormati sudah membudaya pada diri anak sebagai anggota keluarga, maka tidak akan sulit membiasakan hal tersebut ketika berada di masyarakat. Anak-anak dapat memancarkan hubungan saling menghormati kepada teman-teman sekolah, teman kerja dan di dalam organisasi lainnya ${ }^{15}$. Dalam hal ini, hukum taurat tertera perintah yang mengharuskan anak untuk hormat kepada orang tuanya. Hormat berarti anak-anak bertangungjawab memelihara kelangsungan hidup orang tua. Dalam keadaan apapun anak harus tetap menghormati orang tua sehingga menjadi kebiasaan bagi anak dalam kehidupannya. ${ }^{16}$ Bentuk-bentuk menghormati anak kepada orang tua perlu dilakukan dalam keluarga dengan bersikap saling menghormati antara orang tua, anak, dan kepada sesama.

\section{Disiplin}

Setiap anggota keluarga diwajibkan untuk disiplin terhadap aturan-aturan yang ada di dalam keluarga. Di dalam mendisiplinkan anak, kasih merupakan prinsip yang mendasar. Dalam mendisiplinkan anak perlu adanya kasih karena jika tidak ada kasih

\footnotetext{
15 Jarot Wijanarko, Intim Orang Tua-Anak (Jakarta: Keluarga Bahagia Indonesia, 2017), 96.

${ }^{16}$ M . M. Nilam Widyarini, Relasi Orang Tua dan Anak (Jakarta: Elex Media Komputindo, 2013),55.
} 
maka disiplin itu tidak membuahkan hasil, sebaliknya anak akan merasa bahwa disiplin tersebut adalah beban.

Bentuk disiplin yaitu menghargai waktu (waktu belajar, waktu beribadah) dan perilaku. Peran orang tua dalam disiplin waktu belajar yaitu orang tua mengajarkan kepada anak untuk belajar tepat waktu. Sehingga dalam kehidupan anak selalu terbiasa dalam menggunakan waktu secara baik dan benar. Selain itu juga orang tua menanamkan disiplin waktu kepada anak dalam proses belajar dan mendidik anak dapat memakai waktu dengan benar. Banyak hal yang dapat dilakukan oleh orang tua dalam membantu anak-anaknya dalam kegiatan belajar, diantaranya orang tua dapat memberikan perhatian dan bimbingan yang cukup pada anak seperti menyediakan fasilitas belajar, mengawasi kegiatan belajar di rumah, mengawasi penggunaan waktu belajar anak di rumah, mengetahui kesulitan anak dalam belajar, menolong anak mengatasi kesulitannya. Peran orang tua untuk mendisiplinkan anak tentang waktu beribadah yaitu orang tua mengajarkan kepada anak agar bertanggung jawab dalam pelaksanaan ibadah tepat waktu. Sehingga dalam proses pembentukan pribadi anak memiliki disiplin terutama memaknai akan waktu untuk dapat beribadah kepada Tuhan.

Disiplin orang tua mengenai perilaku anak yaitu disiplin terdiri dari dua hal; yang pertama disiplin yang bersifat preventif yaitu membuat peraturan secara bersama-sama seperti tertulis dan tidak tertulis dan sudah disepakati. Kedua disiplin korektif yaitu perilaku anak tidak sesuai dengan aturan yang disepakati di rumah maka anak akan mendapatkan hukuman ini berarti bentuk bentuk disiplin perlu dilakukan oleh orang tua kepada anak dalam keluarga. ${ }^{17}$ Peran orang tua dalam disiplin waktu belajarnya itu orang tua mengajarkan kepada anak untuk belajar tepat waktu sehingga dalam kehidupan anak selalu terbiasa dalam menggunakan waktu secara baik dan benar. Selain itu, orang tua menanamkan disiplin waktu kepada anak dalam proses belajar dan mendidik anak dapat memakai waktu dengan benar. Orang tua memberikan peraturan waktu dan konsekuensi yang sesuai kepada anak dapat belajar melalui kesalahan yang dibuatnya. Orang tua juga berperan dalam mendisiplinkan anak tentang waktu beribadah dalam proses pembentukan pribadi anak. ${ }^{18}$ Anak-anak dididik untuk menyediakan waktu secara rutin untuk merenungkan firman Tuhan, dan taat sepenuhnya terhadap bimbingan rohani.

\footnotetext{
${ }^{17}$ Antonius Atosokhi, Relasi dengan Sesama (Jakarta: Gramedia Pustaka Utama, 2013).

18 Thomas Gordon, Menjadi Orang Tua Efektif (Jakarta: Gramedia Pustaka Utama, 2018), 86.
} 


\section{KESIMPULAN}

Berdasarkan studi tentang sejauhmana orang tua menerapkan bentuk kasih storge kepada kepada anak-anak di dalam keluarga di Gereja Masehi Injili di Timor Jemaat Syalom Oinlasi Barat, maka ditemukan bahwa orang tua sudah cukup melaksanakan dengan baik dan benar. Bahwa orang tua mengayomi anak-anak, orang tua memberikan pengayoman dari tindakan perkelahian, pergaulan bebas dengan cara memberikan nasehat mereka melalui peribadahan keluarga. Memberikan perhatian dengan memastikan anak-anaknya mendapat makanan, pendidikan dan serta terpenuhinya kebutuhan rohani seperti pergi ke gereja, dan ke sekolah minggu; menjadi teladan dengan menenamkan sikap saling mengasihi dan menjadi contoh yang konsisten dalam menanamkan nilai kejujuran; saling menunjukan rasa hormat terhadap anggota keluarga seperti menghargai anggota keluarga saat berbicara; dan menanamkan sikap disiplin waktu belajar dan waktu beribadah. Harapan selanjutnya adalah gereja turut mendukung upaya sadar orangtua tersebut dengan terus memberi edukasi yang komprehensi sehingga orang semakin terampil dalam mendaraskan cara mengasihi yang benar dan baik menurut iman Kristen sehingga anak-anak dalam keluarga Kristen bisa bertumbuh dengan baik dan mampu mimicry cara mengasihi dari orang tuanya terhadap diri dan sesamanya.

\section{Referensi}

Atosokhi, Antonius. Relasi dengan Sesama. Jakarta: Gramedia Pustaka Utama, 2013.

Drescher, Jhon. Melakukan Buah Roh. Jakarta: BPK Gunung Mulia, 2008.

Elisabeth. Pembelajaran Pendidikan Agama Kristen Pada Anak Usia Dini. Bandung: Bina Media Informasi, 2009.

Gordon, Thomas. Menjadi Orang Tua Efektif. Jakarta: Gramedia Pustaka Utama, 2018.

Gunarsa, D. Singgih. Psikologi Praktis Anak, Remaja dan Keluarga. Jakarta: BPK Gunung Mulia, 2008.

Gunarsa, Singgih. "Menanamkan Disiplin Pada Anak." dalam Psikologi Perkembangan Anak dan Remaja, editor Singgih Gunarsa, 86-87. Jakarta: BPK Gunung Mulia, 2008.

Malcom, Brownlee. Pengambilan Keputusan Etis dan Faktor-Faktor di dalamnya. Jakarta: BPK Gunung Mulia, 2006.

Munthe, A. Firman Hidup. Jakarta: BPK Gunung Mulia, 2015.

Praditya, Yusuf. Rahman. Pelindung Diri. Jakarta: YPK Utama, 2020.

Prasetyo, Herry. Agar Anak Merasa di Cintai. Jakarta: Duta Press, 2019. 
Yusuf. Psikologi Perkembangan Anak dan Remaja. Bandung: Rosda, 2009.

Settiawan, Bukik. Anak Bukan Kertas Kosong. Jakarta: Panda Media, 2015.

Sugiyono. Metode Penelitian Kuantitatif, Kualitatif dan R\&D. Bandung: Alfabeta, 2019.

Susetiyo, Benny. Kasih itu Pembebasan. Yogyakarta: Yayasan Pustaka Utama, 2003.

Widyarini, M. M. Nilam. Relasi Orang Tua dan Anak. Jakarta: Elex Media Komputindo, 2013.

Wijanarko, Jarot. Intim Orang Tua-Anak. Jakarta: Keluarga Bahagia Indonesia, 2017. 